versities are not very open to further reforms. This contradicts the widespread impression of the positive experience of institutional reforms and their enthusiastic continuation. The reform fatigue is also working against the efforts of some university leaders-for example, in Dresden (Saxony), Rostock (Mecklenburg-Western Pomerania), and East Berlin. Perhaps more relevant is the fact that the academic environment in East Germany is characterized by a conservative institutional culture. It is very formal, hierarchi$\mathrm{cal}$, preferring frontal instruction in teaching. In short, while entrepreneurial universities are not unthinkable in East Germany, they are improbable.

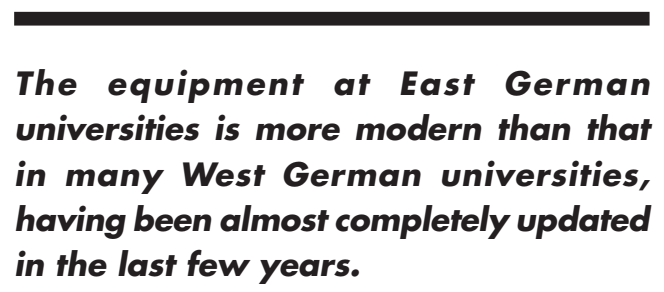

A special problem caused by the transformation of the system concerns the status of middle-aged East German scientists who are now employed at universities in parttime jobs. In 1989, they were between 35 and 45 years old and had to change their focus frequently while hopping from one research project to the next. They proved to be flexible and mobile: 60 percent of all scientists had to leave their original fields and go into another professional area or take early retirement. But now these same scientists are between 45 and 55 years old; they do not, of course, hold professorships (in Germany almost the only opportunity to have a tenured academic job) because to become a professor in Germany is only possible when the aspirant is integrated into the relevant network. But since 1989, the networks are all West German, and for a traditional academic career in West Germany the middle-aged East German scientists are now too old.

Such problems are amplified by another special situation. A lot of young East Germans prefer not to attend university after secondary school. In West Germany, approximately 30 percent of the relevant age cohort takes up studying at the university level, whereas in East Germany only about 20 percent do so. Therefore, the East German universities are not enrolling enough students (except in law, economics and medicine), and the politicians conclude there are too many academic staff. The weaker East German economy results in lower tax revenues for the East German states, and this in turn creates pressure to reduce the budget of higher education institutions. Apart from the change in structures and contents, the newly instituted academic freedom, and the opportunities for international communication, most East German academics experienced the transformation of the universities as a major cutback in jobs in higher education. Moreover, the transformation is not yet complete, inasmuch as the next round of cutbacks in jobs has already been announced.

\title{
Korean National Universities at the Crossroads
}

\section{Toru Umakoshi}

Toru Umakoshi is professor and director of the Center for Higher Education Studies at Nagoya University, Japan. During the 2000-2001 academic year he is visiting professor at Seoul National University, Seoul, Korea. E-mail: <toru@snu.ac.kr>.

Since the economic crisis of 1997-1998 Korean higher $\checkmark$ education reform has emphasized strengthening international competitiveness. The BK-21 Project introduced in the last issue of this newsletter was the first initiative taken by the Korean Ministry of Education. The second initiative is a report entitled "Development Plan of the $\mathrm{Na}$ tional Universities." Released last July, the report reexamines the role and function of national universities as part of an effort to strengthen their academic productiveness and human resources development. The 44 national universities-23 percent of four-year colleges and universities in Korea-are being strongly encouraged to restructure themselves under the guidelines of the report.

\section{Institutional Classification}

The report classifies the national universities into four types of institutions, in accordance with their role and function: (1) research universities ; (2) teaching universities; (3) specialized colleges - such as institutions devoted to ocean engineering, teachers education, and physical education; (4) vocation-oriented colleges to meet the needs of local business and industry. The government would determine financial support based upon the specific purposes of each institution. Private colleges and universities compete for excess funds-a kind of "privatization" policy. Another important recommendation of the panel that put together the report is to improve the geographical distribution of higher education institutions. Consolidating or abolishing the national colleges and universities with similar departments in each of seven regional blocs is strongly urged.

Autonomy and Independence

The report also recommended a reorganization of the gov- 
ernance system of the national universities. In the present system, the national universities come under the direct control of the Ministry of Education. In the report, national universities are encouraged to become "autonomous institutions" independent of the ministry. When a national university decides to become an "autonomous institution," a governance contract is signed by the minister of education and the university president-on the condition that the president is elected through a public recruitment process, by a search committee under the auspices of the Ministry of Education.

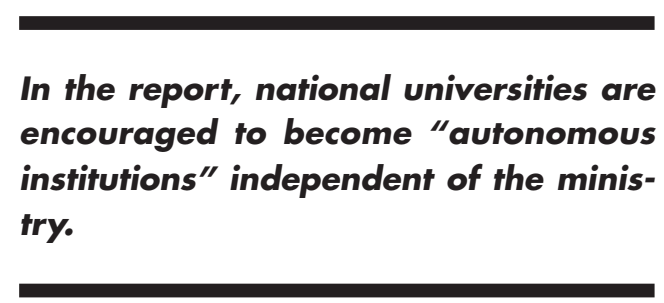

Under the new system, the president become responsible for all matters of university administration, personnel, and finance-independent of the ministry. The president is also free to set the formula for tuition fees. Concurrently, each national university is obliged to establish a "university council" comprised of well-informed people from inside and outside the university. The university council functions as the decision-making organ of the university. As part of this reorganization, the number of clerical staff is to be reduced and staff development activities are to be strengthened.

\section{Improving Teaching and Research}

Another area of reform contained in the report is to reinforce the quality control of teaching and research activities. The national universities are being strongly encouraged to introduce new types of incentives such as a contractbased appointments, a yearly stipend system, and additional benefits to the best researchers and teachers. There is a proposal to modify the present university evaluation system run by the Korean Council for University Education, the Ministry of Education, and the Korean Educational Development Institute by establishing the Committee of University Evaluation, which would integrate the various institutional and discipline-based evaluation procedures into a standardized system.

Following the July public hearing on this report, the Ministry of Education incorporated the opinions of concerned persons into the final version. The reform agenda is to be implemented in three stages: (1) a short-term agenda (2000-2002), (2) an intermediate agenda (2003-2005), and (3) a long-term agenda (2006-2010). The ministry expects that short-term agenda items such as the introduction of the university council and the Committee of University Evaluation will be ready in time for the 2001 government budget.

\section{Criticism within the Professoriate}

Professors from national, local (municipality), and private colleges and universities in the National University Professors Association voiced their criticisms of the report and asked the Ministry of Education to withdraw it. According to newspaper accounts, a number of professors criticized the report as a backing away from the democratic way of university governance that has been realized under the civilian governments of the past seven years. With regard to the reorganization of the national universities, the author is reminded of the bitter experience of failure in the early 1960s under the regime of President Park.

\section{International Higher Education On-line}

Beginning with this issue of $I H E$ we are offering an important new innovation. You can sign up to receive IHE automatically on-line. Sign-up is easy. Simply $\log$ on to our website and follow the instructions in the middle of the page. Once signed on, you will receive the table of contents of each new IHE publication, with links to the full text of every article. This new service will put in you touch with our articles immediately on publication, will permit you to send our articles to colleagues, and allow you to communicate with us through the Internet.

You may not be aware that our on-line site also provides a comprehensive index of articles published in International Higher Education, which includes links to the full text of each article. In this way, you can easily find past information concerning the countries, topics, and authors that have been previously published in IHE-a unique service valuable in research and policy analysis. In addition to the index, our website offers links to other higher education sites, to publications related to the Center for International Higher Education, and to additional information concerning higher education.

These initiatives are just a part of our effort to provide our readers with efficient electronic access to the latest information and analysis concerning higher education worldwide. The programs of the Center are supported by the Ford Foundation and by Boston College as a service to the university community. 